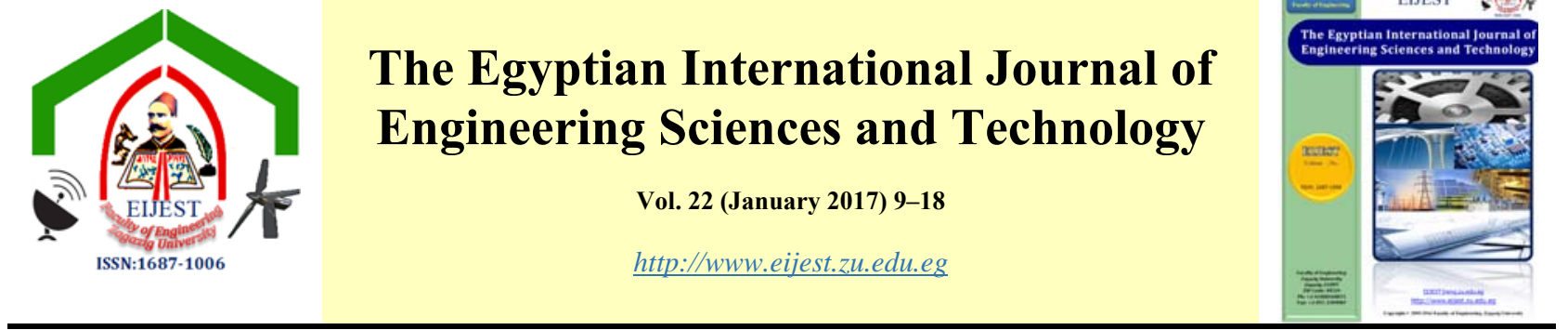

\title{
Using Igneous Rocks as a Coarse Aggregate in Concrete
}

\author{
Mohamed Y. Elsheikh, Ahmed H. Abdel Raheem, Ibrahim Abdel Mohsen * \\ Structural Engineering Depart., Faculty of Eng., Mansoura University, Egypt.
}

\begin{tabular}{l}
\hline A R T I C L E I N F O \\
\hline Article history: \\
Received: 12 May 2016 \\
Received in revised form: \\
20 June, 2 August and 30 \\
August 2016 \\
Accepted: 5 September 2016 \\
Available online: \\
6 September 2016 \\
\hline Keywords: \\
Concrete \\
High strength \\
Self-compacting \\
Aggregate \\
Igneous Rocks \\
Andesite \\
Ryolite
\end{tabular}

\begin{abstract}
A B S T R A C T
The study focuses on producing a new type of concrete utilizing igneous rocks (andesite and ryolite) as a coarse aggregate. Thus, four trail mixes were casted for estimating the concrete materials and proportions, also twenty-three mixes were casted with some variables. Four types of aggregate were used (gravel, dolomite, andesite and ryolite) to show the effect of aggregate type on concrete properties. Four aggregate ratio were used $(1: 1,2: 1,3: 2,5: 2)$ to show the effect of aggregate ratio on the concrete properties. Pozzolanic material (silica fume) was used with $15 \%$ of the cement, water cementatious ratio ranged from ( 0.22$)$, super plasticizer (viscocrete) was used with (1.5) \% of the cement. Ordinary Portland cement was used in all the mixes with cement content $(900) \mathrm{kg} / \mathrm{m}^{3}$. Self-compacting concrete tests (slump flow diameter, slump flow time, L-box, and V-funnel) were prepared on concrete on its fresh phase, hardened concrete tests (compression strength, splitting strength, bending strength, and shemidet hammer) were prepared to identify the mechanical properties of concrete.
\end{abstract}

(C) 2017 EIJEST. All rights reserved.

\section{INTRODUCTION}

\subsection{Definition of Concrete}

Concrete is defined as a composite material which is composed of coarse aggregate, fine aggregate, cement, water, and sometimes admixtures. The concrete can be presented simply as:

Concrete $=$ Filler + Binder

There are many different kinds of concrete. For instance, Portland cement concrete, asphalt concrete, and epoxy concrete. The Portland cement is the one which is used in the concrete construction. Thus, in our thesis, the term concrete usually refers to Portland cement concrete. The composition of the Portland cement concrete can be presented as follows:

$($ Cement + Admixture + water $) \rightarrow$ Cement paste + fine aggregate $\rightarrow$ mort + coarse aggregate $\rightarrow$ concrete

Here we can see that admixtures are needed for

\footnotetext{
* Corresponding author

E-mail address: ibrahim.mohsen.91@hotmail.com.
}

modern practice and thus it become essential for modern concrete.

Any materials other than coarse aggregate, fine aggregate, water, cement and fibers are defined as admixtures, which must be added to the concrete during mixing. There are many features of utilizing admixtures to the concrete such as, controlling the initial and the final setting of concrete, improving the concrete workability and durability, reducing the demand water and reducing the thermal cracks by using silica fume, fly ash or slag.

Concrete can be utilized in many practices. For instance, building frame or bridge, dam, pavement and roads. It is the most commonly construction material in the world. The production of concrete throughout the world is ten times the production of steel by weight and more than thirty times by volume. the production of concrete is over 20 billion tons per year. Although the widely spread out of concrete, it is not as strong or tough as steel [1]. 


\subsection{Effect of Aggregate Properties on Concrete}

Aggregate is commonly considered inert filler, which accounts for 60 to $80 \%$ of the volume and 70 to $85 \%$ by the weight of concrete. Although aggregate is considered inert filler, it is necessary component that defines the concrete's thermal and elastic properties and dimensional stability. Aggregate is classified as two different types, coarse and fine. Coarse aggregate is usually greater than $4.74 \mathrm{~mm}$ (retained on a No. 4 sieve), while fine aggregate is less than $4.75 \mathrm{~mm}$ (passing the No. 4 sieve). The compressive aggregate strength is an important factor in the selection of the aggregate. When determining the strength of normal concrete, most concrete aggregates are several times stronger than the other component $\mathrm{s}$ in concrete and therefore not a factor in the strength of normal strength concrete. Lightweight aggregate concrete may be more influenced by the compressive strength of the aggregates.

Other physical and mineralogical properties of aggregate must be known before mixing concrete to obtain a desirable mixture. [2,3,4].

\subsection{Igneous Rocks}

Igneous rocks are formed from solidification and cooling of magma. This magma can be derived from partial melts of pre-existing rocks in either planet's mantle or crust. Typically, the melting of rocks is caused by one or more of three process namely; an increase in temperature, a decrease in pressure, or a change in composition. Igneous comes from word "igins" meaning fire, its therefore not surprising that igneous rocks are associated with volcanic activity and their distributions is controlled by plate tectonics. one of the appealing aspects of the plate tectonics is that it accounts for reasonably well for the variety of igneous rocks and distribution [5]. Igneous rocks are divided into two main categories as shown in table (1); Plutonic (intrusive) rock and volcanic (extrusive). Intrusive rocks result when magmas cool and crystallizes slowly within the Earth crust. A common example of this type is granite. Extrusive rocks results from magma reaching the surface either as lava or fragmental ejecta, forming rocks such as pumice and basalt.

Basic minerals, such as olivine and pyroxene, are also referred to ferromagnesian based on their composition. Since these minerals are darker in color, igneous rocks containing them are darker. Likewise, acidic minerals such as quartz, alkali feldspar, and muscovite, are referred to as non-ferromagnesian.
Rocks containing non-ferromagnesian are more silica rich and lighter in color.

We will use the color index, to quantify the amount of silica and darker minerals for samples of igneous rocks. We will then classify their composition as either acidic (acidic), intermediate, basic, or ultra-basic. Next, we will lock at crystal size and determine if the rock cooled slowly, inside the earth (intrusive), or more quickly at earth surface (extrusive), using the igneous rock classification chart.

Table (1) Classification of igneous rocks [6].

\begin{tabular}{|l|l|c|l|}
\hline $\begin{array}{l}\text { Rock } \\
\text { Name }\end{array}$ & Main Minerals & Composition & Cooling Rate \\
\hline Granite & $\begin{array}{l}\text { Quartz, Alkali } \\
\text { feldspar, plagioclase } \\
\text { (minor; biotitic, } \\
\text { hornblende) }\end{array}$ & Acidic & Intrusive \\
\hline Ryolite & $\begin{array}{l}\text { Quartz, Alkali } \\
\text { feldspar, Plagioclase } \\
\text { (minor; biotitic, } \\
\text { hornblende) }\end{array}$ & $\begin{array}{l}\text { Acidic } \\
\text { Diorite } \\
\text { (minor; quartz, } \\
\text { biotitic, hornblende) }\end{array}$ & Extrusive \\
\hline Andesite & $\begin{array}{l}\text { Plagioclase Feldspar } \\
\text { (minor; quarts, } \\
\text { biotitic, hornblende) }\end{array}$ & intermediate & Extrusive \\
\hline Gabbros & $\begin{array}{l}\text { Plagioclase Feldspar, } \\
\text { Pyroxene } \\
\text { (minor; olivine) }\end{array}$ & Basic & Intrusive \\
\hline Basalt & $\begin{array}{l}\text { Plagioclase Feldspar, } \\
\text { Pyroxene } \\
\text { (minor; Olivine) }\end{array}$ & Basic & Extrusive \\
\hline Peridotite & Pyroxene, Olivine & Ultra-basic & Intrusive \\
\hline Dunite & Olivine & Ultra- basic & Intrusive \\
\hline
\end{tabular}

\subsubsection{Andesite [7,8]}

Andesite is the name used for a family of finegrained, extrusive igneous rocks that are usually light to dark gray in color as shown in Fig.(1). It is rich in Plagioclase feldspar minerals and may contain biotitic, pyroxene, or amphibole. Andesite usually does not contain quartz or olivine.

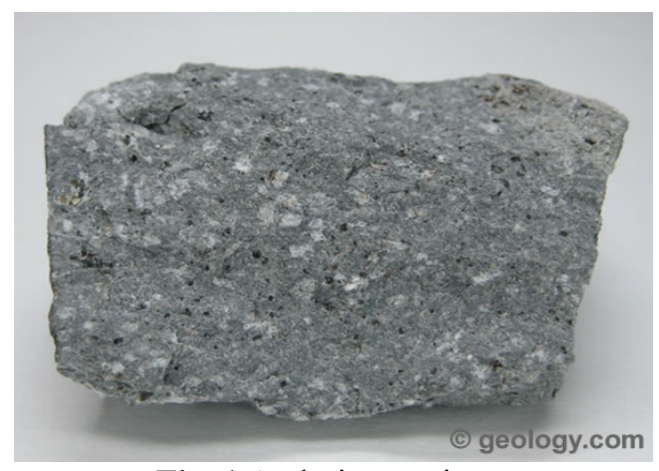

Fig. 1 Andesite specimen 


\section{Properties of andesite}

- The auxiliary minerals that the rock may contain are apatite, garbed, limonite, biotitic, magnetite, zircon. It may contain trace amount of alkali feldspar as well.

- It is moderate in its silica content. That is, it is neither rich nor deficient in this mineral. The silica content is $50-65 \%$.

- The density of this type of rocks is 2.11 $2.36 \mathrm{gm} / \mathrm{cm}^{3}$.

- The specific gravity of the rock is $2.5-2.8$.

- It generally occurs in the hues of gray. However, it is lighter in color that basalt.

-It is said to form thicker fluxes or domeshaped structures.

\section{Uses of andesite rock}

1) It finds its chief uses in the construction and road-making industries for making roadbeds. It is used as a filler or sometimes added as a constituent to various component.

2) It is used in making statues and monuments. Besides this, it is used in designing landscape and gardens.

3) Its resistance to slip makes it very apt to be used in making tiles.

\subsubsection{Ryolite $[7,8]$}

Ryolite is an extrusive igneous rock with a very high silica content. It is usually pink or gray in color as shown in Fig.(2) with grains so small that they are difficult to observe without a hand lens. Ryolite is made of quartz, Plagioclase and sanidine, with minor amounts of hornblende and biotitic.

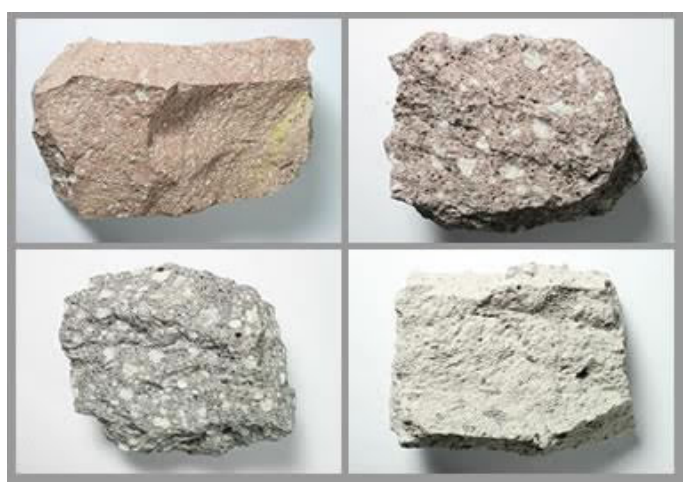

Fig. 2 Several specimens of ryolite porphyry.

\section{Uses of ryolite}

1) Ryolite is used in cements, which is widely used in the creation of skyscrapers and houses.

2) Obsidian ryolites were used by the Maori as a cutting tool, as well as for weapons.

3) Ryolites are used in decorative stones, as well as ornamental stones in jewelry.

4) Pumice ryolites are also used as healing stones, as well as an abrasive in the cosmetic industry.

Ryolite rocks are found in the countries of New Zealand, Germany, Iceland, India, and China. Deposits are normally formed near active or extinct volcanoes. Though, there have been only 3 appearances in the 20th century, namely, the Novarupta Volcano in Alaska, St. Andrew Strait Volcano in Papua New Guinea, and Chaitén Volcano in South Chile.

\subsubsection{Local Andesite and Ryolite in Egypt}

North-west of Hurghada along the western cost of the Red Sea, Gebel Dokhan, Wadi Um Sidra, Wadi Um Asmer, WadiZareib as shown in Fig.(3).

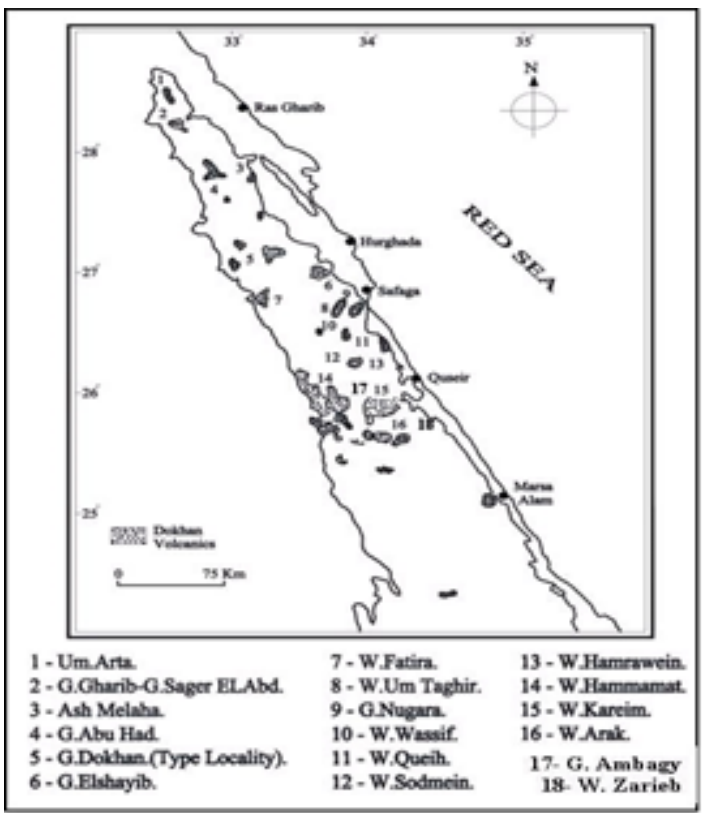

Fig. 3 Dokhan Volcanic outcrops in the Eastern Desert of Egypt [9]. 
Mohamed Y. Elsheikh et.al.. / Using Igneous Rocks as a Coarse Aggregate in Concrete

Table (2) Experimental plan.

\begin{tabular}{|c|c|c|c|c|c|c|c|c|c|c|c|c|}
\hline \multicolumn{2}{|c|}{ Mix } & \multicolumn{2}{|c|}{ Coarse Aggregate } & \multirow{2}{*}{$\begin{array}{c}\begin{array}{c}\text { Fine } \\
\text { Aggregate }\end{array} \\
\begin{array}{c}\text { Cont } \\
\mathrm{kg} / \mathrm{m}^{3}\end{array}\end{array}$} & \multicolumn{2}{|c|}{ Cement } & \multicolumn{2}{|c|}{ S. F } & \multicolumn{2}{|c|}{ Viscocrete } & \multirow{2}{*}{$\begin{array}{l}\text { Water } \\
\mathrm{kg} / \mathrm{m}^{3}\end{array}$} & \multirow[t]{2}{*}{$\mathbf{W} / \mathbf{C M}$} \\
\hline no & cast & Type & $\begin{array}{c}\text { Cont } \\
\mathrm{kg} / \mathrm{m}^{3}\end{array}$ & & Type & $\begin{array}{l}\text { content } \\
\mathrm{kg} / \mathrm{m}^{3}\end{array}$ & $\begin{array}{c}\text { Cont } \\
\mathrm{kg} / \mathrm{m}^{3}\end{array}$ & Ratio & $\begin{array}{c}\text { cont } \\
\mathrm{kg} / \mathrm{m}^{3}\end{array}$ & Ratio & & \\
\hline M1 & G6 & Gravel & 912 & 456 & $\mathrm{OPC}$ & 900 & ...... & $\ldots \ldots$ & ...... & $\ldots \ldots$ & 198 & 0.22 \\
\hline M2 & D6 & Dolomite & 900.6 & 450.3 & $\mathrm{OPC}$ & 900 & $\ldots \ldots$ & $\ldots \ldots$ & $\ldots \ldots$ & $\ldots \ldots$ & 198 & 0.22 \\
\hline M3 & A6 & Andesite & 886.5 & 443.25 & OPC & 900 & $\ldots \ldots$ & $\ldots \ldots$ & $\ldots \ldots$ & $\ldots \ldots$ & 198 & 0.22 \\
\hline M4 & R6 & Ryolite & 919 & 459.5 & $\mathrm{OPC}$ & 900 & & & $\ldots \ldots$ & $\ldots \ldots$ & 198 & 0.22 \\
\hline M5 & G7 & Gravel & 733.75 & 366.9 & OPC & 900 & 135 & $15 \%$ & 13.5 & $1.50 \%$ & 227.7 & 0.22 \\
\hline M6 & D7 & Dolomite & 724.5 & 362.25 & $\mathrm{OPC}$ & 900 & 135 & $15 \%$ & 13.5 & $1.50 \%$ & 227.7 & 0.22 \\
\hline M7 & A7 & Andesite & 713.2 & 356.5 & $\mathrm{OPC}$ & 900 & 135 & $15 \%$ & 13.5 & $1.50 \%$ & 227.7 & 0.22 \\
\hline M8 & R7 & Ryolite & 739.3 & 369.6 & OPC & 900 & 135 & $15 \%$ & 13.5 & $1.50 \%$ & 227.7 & 0.22 \\
\hline M9 & G8 & Gravel & 550.3 & 550.3 & $\mathrm{OPC}$ & 900 & 135 & $15 \%$ & 13.5 & $1.50 \%$ & 227.7 & 0.22 \\
\hline M10 & D8 & Dolomite & 545 & 545 & $\mathrm{OPC}$ & 900 & 135 & $15 \%$ & 13.5 & $1.50 \%$ & 227.7 & 0.22 \\
\hline M11 & A8 & Andesite & 538.65 & 538.65 & $\mathrm{OPC}$ & 900 & 135 & $15 \%$ & 13.5 & $1.50 \%$ & 227.7 & 0.22 \\
\hline M12 & $\mathrm{R} 8$ & Ryolite & 553.4 & 553.4 & $\mathrm{OPC}$ & 900 & 135 & $15 \%$ & 13.5 & $1.50 \%$ & 227.7 & 0.22 \\
\hline M13 & G9 & Gravel & 660.4 & 440.25 & OPC & 900 & 135 & $15 \%$ & 13.5 & $1.50 \%$ & 227.7 & 0.22 \\
\hline M14 & D9 & Dolomite & 652.8 & 435.25 & $\mathrm{OPC}$ & 900 & 135 & $15 \%$ & 13.5 & $1.50 \%$ & 227.7 & 0.22 \\
\hline M15 & A9 & Andesite & 643.75 & 429 & $\mathrm{OPC}$ & 900 & 135 & $15 \%$ & 13.5 & $1.50 \%$ & 227.7 & 0.22 \\
\hline M16 & R9 & Ryolite & 664.8 & 443.25 & $\mathrm{OPC}$ & 900 & 135 & $15 \%$ & 13.5 & $1.50 \%$ & 227.7 & 0.22 \\
\hline M17 & G10 & Gravel & 786.15 & 314.5 & $\mathrm{OPC}$ & 900 & 135 & $15 \%$ & 13.5 & $1.50 \%$ & 227.7 & 0.22 \\
\hline M18 & D10 & Dolomite & 775.5 & 310.2 & $\mathrm{OPC}$ & 900 & 135 & $15 \%$ & 13.5 & $1.50 \%$ & 227.7 & 0.22 \\
\hline M19 & A10 & Andesite & 762.6 & 305 & $\mathrm{OPC}$ & 900 & 135 & $15 \%$ & 13.5 & $1.50 \%$ & 227.7 & 0.22 \\
\hline M20 & R10 & Ryolite & 792.5 & 317 & $\mathrm{OPC}$ & 900 & 135 & $15 \%$ & 13.5 & $1.50 \%$ & 227.7 & 0.22 \\
\hline \multirow{2}{*}{ M21 } & \multirow{2}{*}{$\begin{array}{c}(\mathrm{A}+\mathrm{R}) 4 \\
1: 1\end{array}$} & Andesite & 273 & \multirow{2}{*}{545.9} & \multirow{2}{*}{$\mathrm{OPC}$} & \multirow{2}{*}{900} & \multirow{2}{*}{135} & \multirow{2}{*}{$15 \%$} & \multirow{2}{*}{13.5} & \multirow{2}{*}{$1.50 \%$} & \multirow{2}{*}{227.7} & \multirow{2}{*}{0.22} \\
\hline & & Ryolite & 273 & & & & & & & & & \\
\hline \multirow{2}{*}{ M22 } & \multirow{2}{*}{$\begin{array}{c}(\mathrm{A}+\mathrm{R}) 5 \\
2: 1\end{array}$} & Andesite & 362.3 & \multirow{2}{*}{543.5} & \multirow{2}{*}{ OPC } & \multirow{2}{*}{900} & \multirow{2}{*}{135} & \multirow{2}{*}{$15 \%$} & \multirow{2}{*}{13.5} & \multirow{2}{*}{$1.50 \%$} & 2077 & קר? \\
\hline & & Ryolite & 181.2 & & & & & & & & & 0.22 \\
\hline 423 & $(\mathrm{~A}+\mathrm{R}) 6$ & Andesite & 182.8 & 5485 & $\Omega \mathrm{PC}$ & 000 & 135 & 150 & 135 & $150 \%$ & 2277 & ?27 \\
\hline $1 \mathrm{VIZJ}$ & $1: 2$ & Ryolite & 365.7 & 040.0 & CIC & 300 & (1J) & 1070 & 10.0 & 1.0070 & 221.1 & 0.22 \\
\hline & & & & $\mathrm{A}+\mathrm{R}: \mathrm{A}$ & $\begin{array}{r}R \\
\text { esite to } \\
\text { S.F: } S\end{array}$ & $\begin{array}{l}\text { Sravel } \\
\text { olomite } \\
\text { Andesite } \\
\text { 2yolite } \\
\text { olite (2:1 } \\
\text { ica Fume }\end{array}$ & :2), (1 & & & & & \\
\hline
\end{tabular}

proportions. Table1 shows a general survey of these

\section{EXPERIMENTAL PLAN}

Three groups of concrete with a total number of 23 mixes were prepared and investigated to satisfy the main objectives of the paper, beside the four trial mixes to investigate the materials and their groups and the used materials, Ordinary Portland cement (OPC) was used in all the 23 mixes. The three groups were prepared with cement content $=900$ $\mathrm{kg} / \mathrm{m}^{3}$ and water cementitious ratio $=0.22$. Group A is a normal strength concrete (NSC) without any admixtures, while groups $\mathrm{B}$ and $\mathrm{C}$ were casted using 
admixtures (viscocrete and silica fume). Gravel, Dolomite, Andesite, Ryolite were used as coarse aggregate with different ratios. Table. (2) illustrated the experimental plan of all the mixes.

\subsection{Materials}

\subsubsection{Fine aggregate}

A natural sand with fineness modulus of 3.00, specific gravity of 2.65 and unit weight of 1750 $\mathrm{kg} / \mathrm{m}^{3}$ was used in this research According to the Egyptian specification (1109:2008) [10].

\subsubsection{Coarse aggregate}

Four types of aggregates were used in this research. These types are Gravel, Dolomite, Andesite and ryolite, the properties of aggregates are shown in Table (3).

Table (3) Main properties of aggregates.

\begin{tabular}{|c|c|c|c|c|c|}
\hline Type & $\begin{array}{c}\text { Specific } \\
\text { Gravity }\end{array}$ & $\begin{array}{c}\text { Unit } \\
\text { weight } \\
\mathrm{kg} / \mathrm{m}^{3}\end{array}$ & $\begin{array}{c}\text { Maximum } \\
\text { Nominal } \\
\text { Size (mm) }\end{array}$ & $\begin{array}{c}\text { Water } \\
\text { Absor. }\end{array}$ & $\begin{array}{l}\text { Crushing } \\
\text { Value }\end{array}$ \\
\hline Sand & 2.65 & 1750 & ------ & ----- & ------ \\
\hline Gravel & 2.65 & 1620 & 10 & 1.5 & 32 \\
\hline Dolomite & 2.6 & 1600 & 10 & 1.55 & 28 \\
\hline Andesite & 2.54 & 1560 & 10 & 1.55 & 17 \\
\hline Ryolite & 2.68 & 1575 & 10 & 1.6 & 19 \\
\hline
\end{tabular}

X-Ray Diffraction was carried out as shown in Figs. $(4,5)$, Tables $(4,5)$ and X-Ray fluorescence was carried out as shown in Table (6).

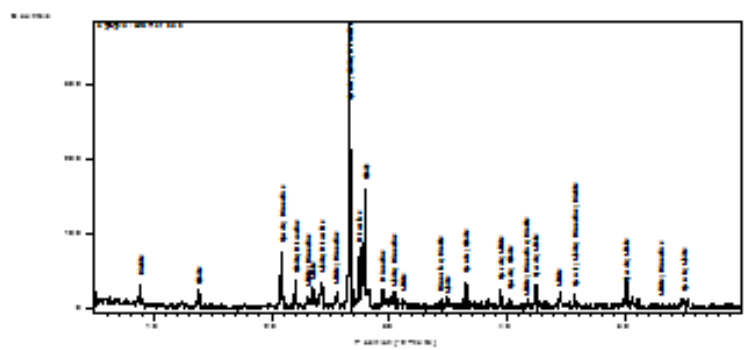

Fig. 4 X-ray diffraction for andesite rock [11].

Environmental conditions: Temperature: $25 \pm 2{ }^{\circ} \mathrm{C}$ Humidity: $45 \pm 2 \%$
Table (4) X-Ray diffraction composition for andesite.

\begin{tabular}{|l|l|}
\hline Compound Name & Chemical Formula \\
\hline Quartz & $\mathrm{Si} \mathrm{O}_{2}$ \\
\hline Albeit & $\left(\mathrm{Na}_{0.98} \mathrm{Ca}_{0.02}\right)\left(\mathrm{Al}_{1.02} \mathrm{Si}_{2.98} \mathrm{O}_{8}\right)$ \\
\hline Microcline & $\mathrm{K} \mathrm{Al} \mathrm{Si} \mathrm{O}_{8}$ \\
\hline Biotitic & $(\mathrm{K}, \mathrm{H})_{2}\left(\mathrm{Mg}, \mathrm{Fe}^{+2}\right)_{2}\left(\mathrm{Al}, \mathrm{Fe}^{+3}\right)_{2}\left(\mathrm{Si} \mathrm{O}_{4}\right)_{3}$ \\
\hline
\end{tabular}

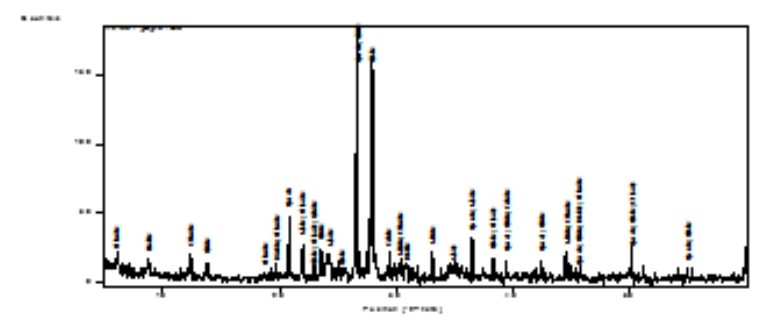

Fig. 5 X-ray diffraction for ryolite rock [11].

Environmental conditions: Temperature: $25 \pm 2^{\circ} \mathrm{C}$ Humidity: $45 \pm 2 \%$

Table (5) X-Ray diffraction composition for ryolite.

\begin{tabular}{|l|l|}
\hline Compound Name & Chemical Formula \\
\hline Quartz & $\mathrm{SiO}_{2}$ \\
\hline Albeit & $\left(\mathrm{Na}_{0.98} \mathrm{Ca}_{0.02}\right)\left(\mathrm{Al}_{1.02} \mathrm{Si}_{2.98} \mathrm{O}_{8}\right)$ \\
\hline Biotitic & $(\mathrm{K}, \mathrm{H})_{2}\left(\mathrm{Mg}, \mathrm{Fe}^{+2}\right)_{2}\left(\mathrm{Al}, \mathrm{Fe}^{+3}\right)_{2}\left(\mathrm{Si} \mathrm{O}_{4}\right)_{3}$ \\
\hline Chlorite & $\mathrm{Mg}_{2} \mathrm{Al}_{3}\left(\mathrm{Si}_{3} \mathrm{Al}\right) \mathrm{O}_{10}(\mathrm{O})_{8}$ \\
\hline Calcite & $\mathrm{Ca} \mathrm{C \textrm {O } _ { 3 }}$ \\
\hline
\end{tabular}

Table (6) X-Ray fluorescence for andesite and ryolite rocks [11]

\begin{tabular}{|c|c|c|c|}
\hline \multirow{4}{*}{} & Sample name & Ryolite & Andesite \\
\cline { 2 - 4 } & $\mathrm{SiO}_{2}$ & 67.04 & 53.10 \\
\cline { 2 - 4 } & $\mathrm{Al}_{2} \mathrm{O}_{3}$ & 14.90 & 15.80 \\
\cline { 2 - 4 } & $\mathrm{Fe}_{2} \mathrm{O}_{3}$ & 2.59 & 7.36 \\
\cline { 2 - 4 } & $\mathrm{CaO}$ & 3.27 & 5.45 \\
\cline { 2 - 4 } 芦 \\
\cline { 2 - 4 } \\
\cline { 2 - 4 } \\
\cline { 2 - 4 }
\end{tabular}

\subsubsection{Cement}

Ordinary Portland cement with physical properties, Specific gravity $=3.15$, Initial setting time $=65 \mathrm{~min}$ and final setting time $=280 \mathrm{~min}$ According to Egyptian specification (ES 2421:2009) [12]. 


\subsubsection{Silica fume}

A mineral admixture (silica fume) was used in the design of the concrete mix, Silica fume is produces by the Ferro Silicon Alloys factory in Edfu, Aswan, with a specific gravity equal 2.25 and specific surface area of $17 \times 10^{3} \mathrm{~m}^{2} / \mathrm{kg}$.

\subsubsection{Super plasticizer (Viscocrete- 3425)}

viscocrete-3425 type $F$ and $G$ with density of $1.08 \mathrm{~kg} / \mathrm{lit}$.

\subsection{Tests of Fresh Concrete}

Three tests of fresh concrete were done to check to properties of SCC (filling ability, passing ability (free from blocking at reinforcement) and its resistance to segregation (stability):

- slump flow test.

- V-funnel test.

- L-box test.

\subsection{Tests of Hardened Concrete}

- Compression test after 7, 28, and 56 days was carried out on;

- $100 \mathrm{~mm}$ cubes

- Splitting test after 7, 28, and 56 days was carried out:

- $150 \times 300 \mathrm{~mm}$ cylinders

- Flexural strength test after 7,28, and 56 days was carried out;

- $100 \times 100 \times 500 \mathrm{~mm}$ prisms

\section{RESULTS}

\subsection{Fresh Concrete}
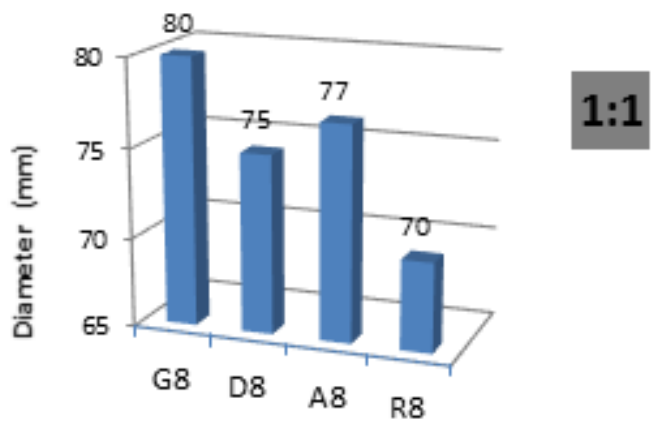

Fig. 6 The slump flow diameter of four mixes with different aggregate type at aggregate ratio of 1:1

As the diameter increases, the flow ability of fresh SCC increases. Thus the best aggregate type for the flow ability are respectively (gravel, andesite, dolomite, ryolite)

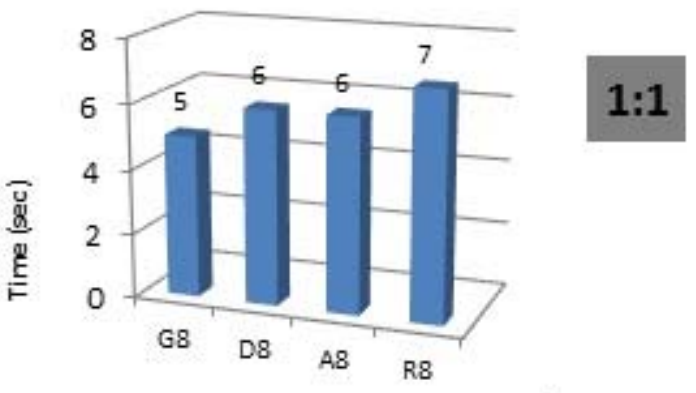

Aggregate type

Fig. 7 The slump flow time $\left(T_{50}\right)$ of four mixes with different aggregate type at aggregate ratio of 1:1

As the time decreases, the flow ability of fresh SCC increases. Thus the best aggregate type for the flow ability are respectively (gravel, andesite, dolomite, ryolite).

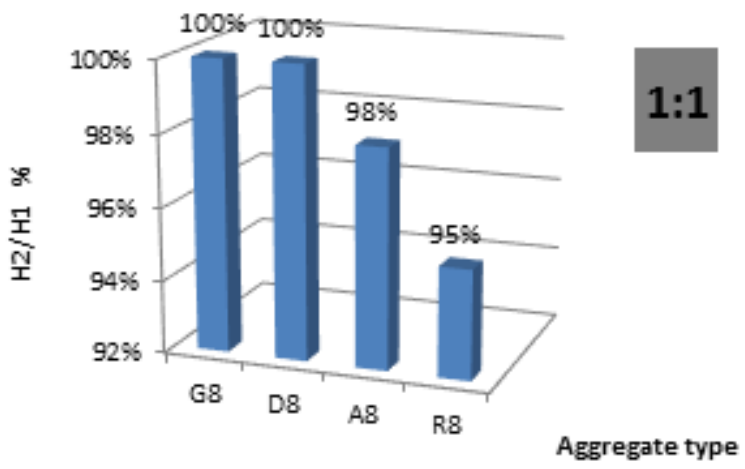

Fig. 8 The passing ability (H2/H1) of four mixes with different aggregate type at aggregate ratio of 1:1

As the ratio of $h_{2} / h_{1}$ increases, the passing ability of fresh SCC increases. Thus the best aggregate type for the flow ability are respectively (gravel, dolomite, andesite, ryolite).

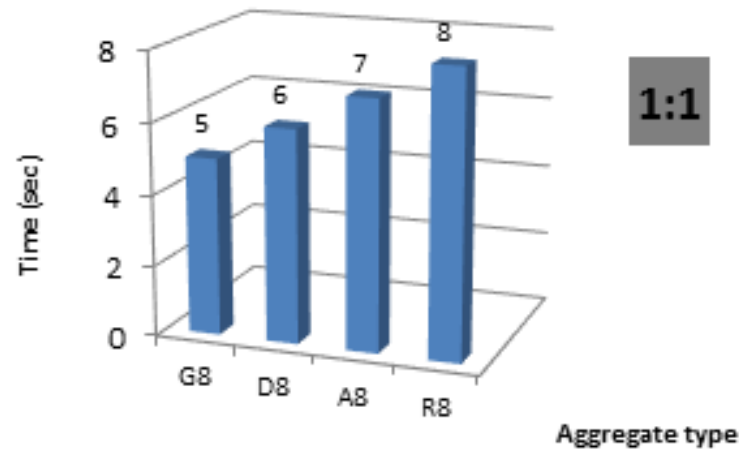

Fig. 9 The V-funnel (T0) of four mixes with different aggregate type at aggregate ratio of 1:1 
As the time decreases, the flow ability of fresh SCC increases. Thus the best aggregate type for the flow ability are respectively (gravel, dolomite, andesite, ryolite).

\subsubsection{The effect of aggregate type}

Using the gravel as coarse aggregate provide more workability, filling ability and passing ability more than using crushed stone and volcanic rocks as shown in Figs. $(6,7,8,9)$ for many reasons:

-The gravel has a rounded shape with a smooth surface area. However, the crushed stone and volcanic rocks have an angular shape we a roughness surface area.

-Crushed stone and volcanic rocks needs more water than the gravel to achieve the fresh properties of SCC, due to its high absorption ratio compared with the aggregate.

\subsubsection{The effect of aggregate ratio}

As the Aggregate ratio increases the properties of fresh SCC decreases due to

-The increase in the aggregate ratio may lead to segregation.

-Blockage may appear specially in the confined zone due to reinforcement.

\subsubsection{The effect of cement content and $\mathrm{W} / \mathrm{CM}$}

As the cement content increases and the W/CM decreases, the properties of fresh SCC decreases, because while the cement content increase, it needs more water to achieve the same workability and flow ability.

\subsection{Hardened Concrete \\ 3.2.1 Effect of aggregate type}

i. The compressive strength increases using ryolite, dolomite, andesite, and gravel respectively as a coarse aggregate in concrete.

ii. The splitting strength increases using andesite, ryolite, dolomite, and gravel respectively as a coarse aggregate in concrete.

iii. The bending strength increases using ryolite, dolomite, andesite, and gravel respectively as a coarse aggregate in concrete.

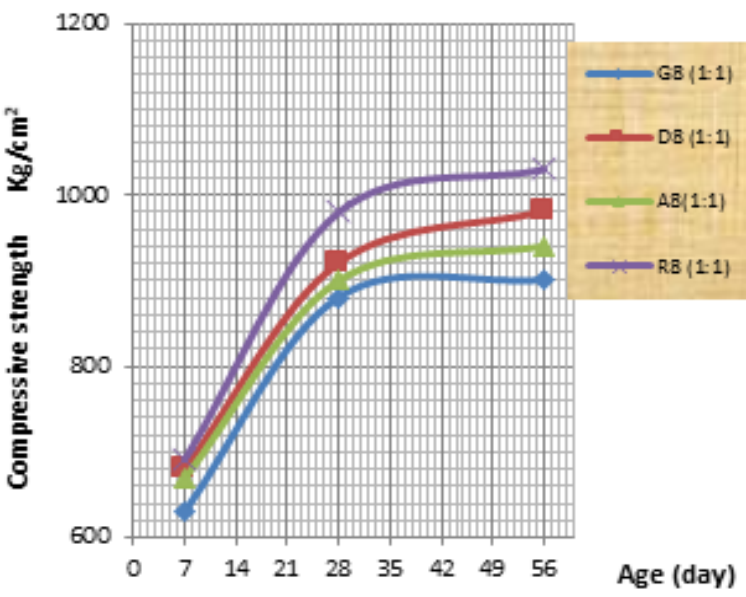

Fig. 10 Relationship between the compressive strength and the age showing the aggregate type at aggregate ratio $1: 1$

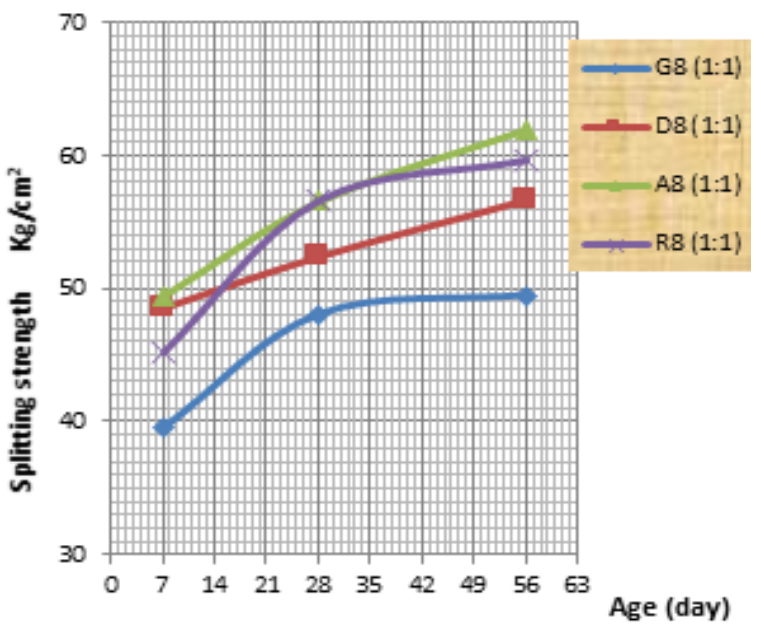

Fig. 11 Relationship between the splitting strength and the age showing the aggregate type at aggregate ratio 1:1

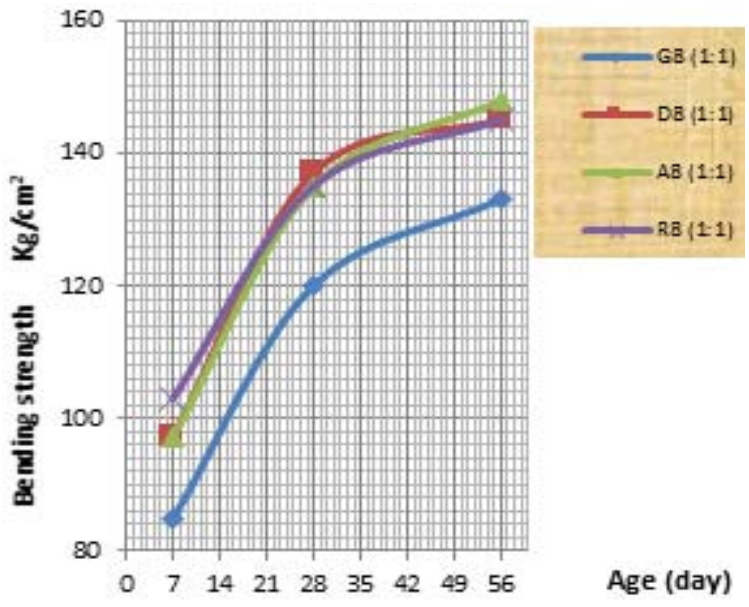

Fig. 12 Relationship between the bending strength and the age showing the aggregate type at aggregate ratio $1: 1$ 
Figs. $(10,11,12)$ show that:

- The rounded shape and the smooth surface area of the gravel may negatively affect the concrete strength.

-Using gravel as coarse aggregate in HSSCC may affect the result negatively, cause the strength of the cement paste may beyond the strength of the gravel in HSSCC and the failure may occur through the gravel.

\subsubsection{Effect of aggregate ratio for andesite}

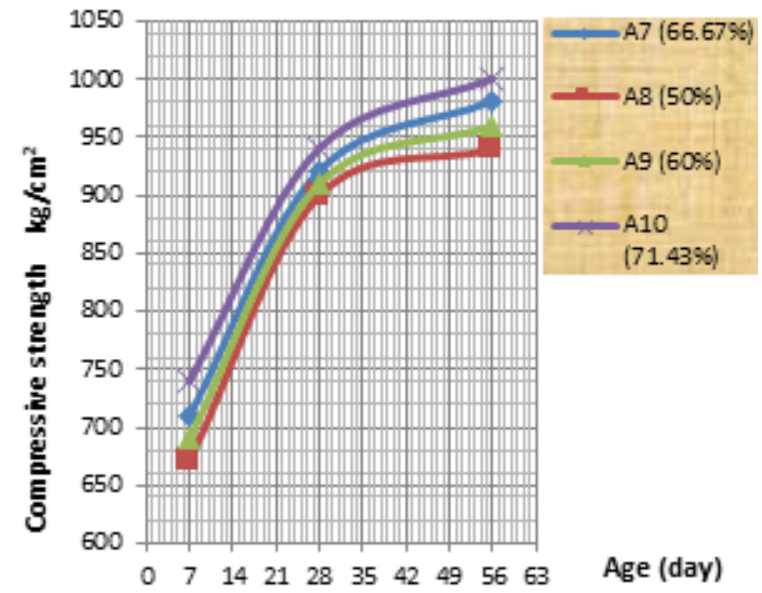

Fig. 13 Relationship between compressive strength and the age showing the effect of andesite ratio at cement content $=$ $900 \mathrm{~kg} / \mathrm{m}^{3}$

The compressive strength increases using the andesite ratio $(5: 2), \quad(2: 1), \quad(3: 2), \quad$ and $(1: 1)$ respectively as a coarse aggregate in concrete.

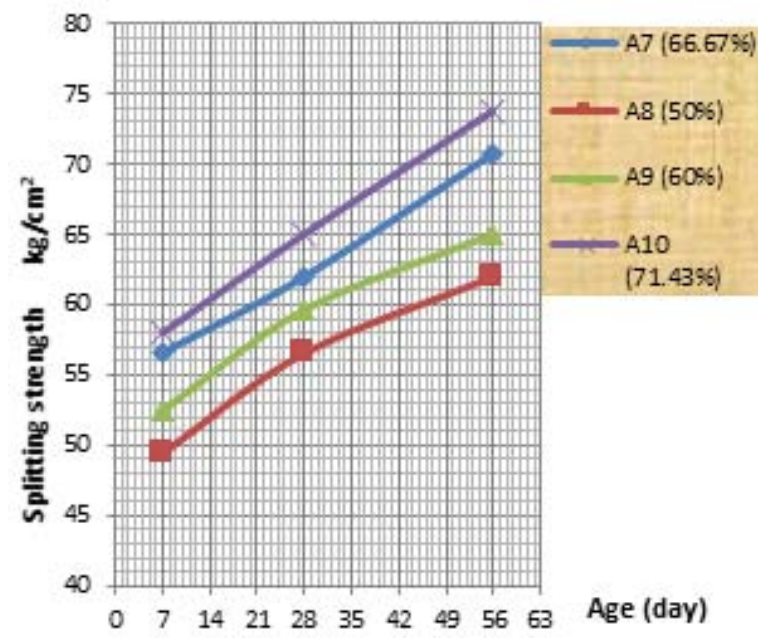

Fig. 14 Relationship between splitting strength and the age showing the effect of andesite ratio at cement content $=900$ $\mathrm{kg} / \mathrm{m}^{3}$
The splitting strength increases using the andesite ratio (5:2), (2:1), (3:2), and (1:1) respectively as a coarse aggregate in concrete.

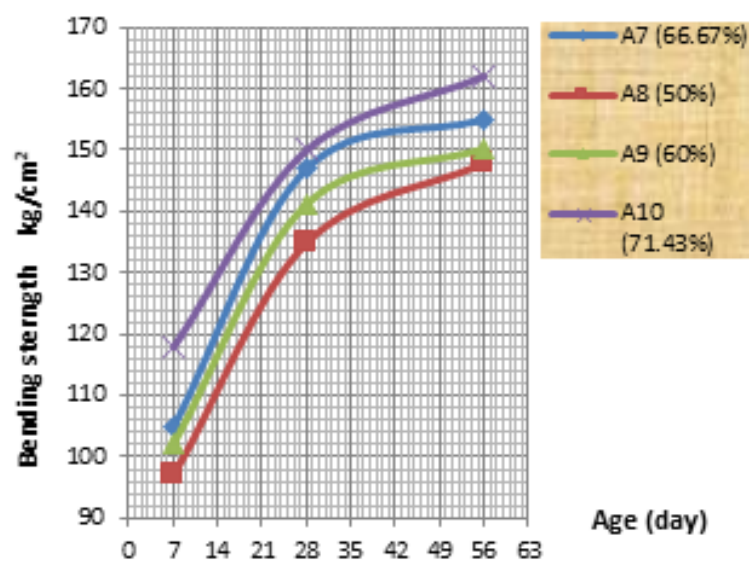

Fig. 15 Relationship between bending strength and the age showing the effect of andesite ratio at cement content $=900$ $\mathrm{kg} / \mathrm{m}^{3}$

The bending strength increases using the andesite ratio $(5: 2),(2: 1),(3: 2)$, and $(1: 1)$ respectively as a coarse aggregate in concrete.

\subsubsection{Effect of aggregate ratio for ryolite}

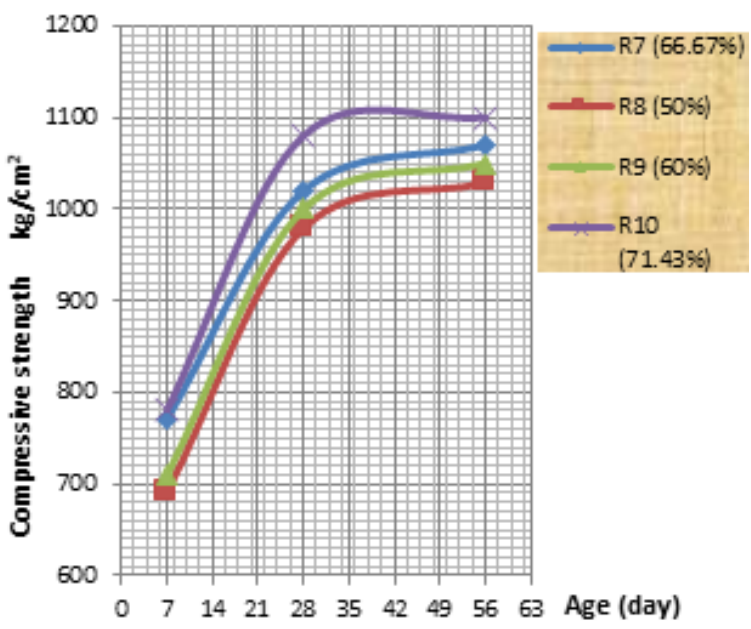

Fig. 16 Relationship between compressive strength and the age showing the effect of ryolite ratio at cement content $=$ $900 \mathrm{~kg} / \mathrm{m}^{3}$

-The compressive strength increases using the ryolite ratio $(5: 2),(2: 1),(3: 2)$, and $(1: 1)$ respectively as a coarse aggregate in concrete.

-The splitting strength increases using the ryolite ratio $(5: 2),(2: 1),(3: 2)$, and (1:1) respectively as a coarse aggregate in concrete. 


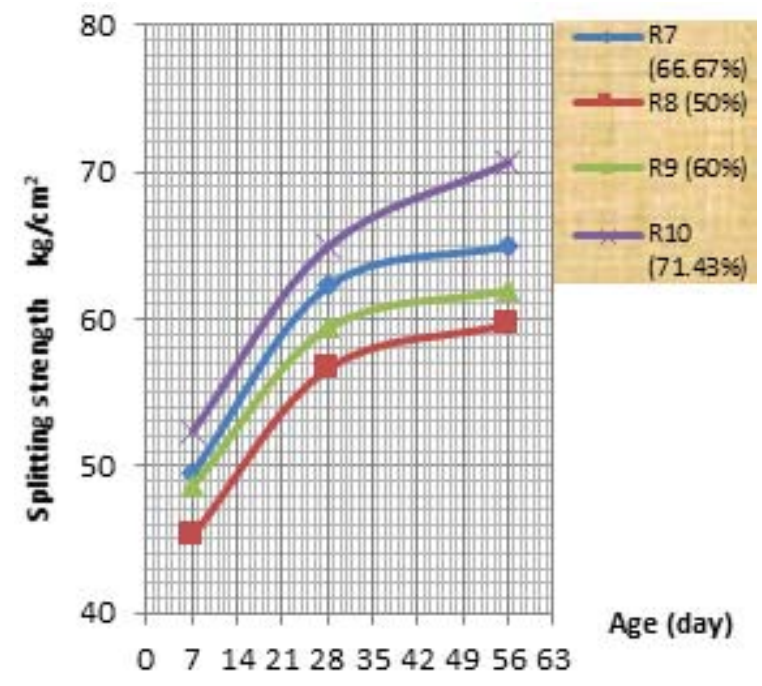

Fig. 17 Relationship between splitting strength and the age showing the effect of ryolite ratio at cement content $=900$ $\mathrm{kg} / \mathrm{m}^{3}$

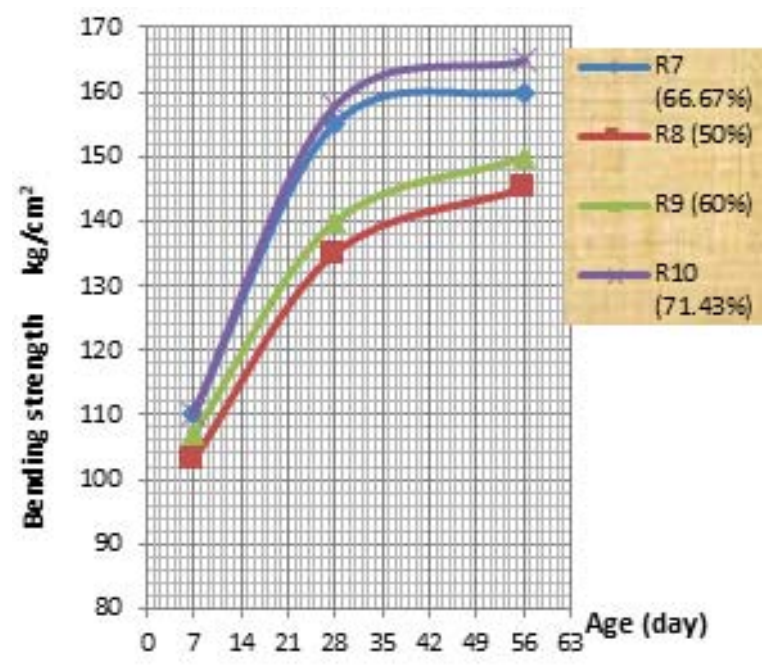

Fig. 18 Relationship between bending strength and the age showing the effect of ryolite ratio at cement content $=900$ $\mathrm{kg} / \mathrm{m}^{3}$

-The bending strength increases using the ryolite ratio (5:2), (2:1), (3:2), and (1:1) respectively as a coarse aggregate in concrete.

Figs. $(13,14,15,16,17,18)$ show that:

- The best aggregate ratio for dolomite, andesite, and rhyolite (cement content $=900$ $\left.\mathrm{kg} / \mathrm{m}^{3}\right)$ is $5: 2(71.43 \%)$, because both the aggregate and the cement paste share the stresses at this ratio, the failure may occur through the aggregate or through the cement best.
- In contrast, when we use another ratio of aggregate, the failure occurs only on the aggregate, due to the strong of the cement paste.

\section{CONCLOSIONS}

1) Using the gravel as coarse aggregate provide more workability, filling ability and passing ability, due to its rounded shape and smooth surface area.

2) Crushed stone and volcanic rocks affect the properties of SCC negatively as compared with the gravel, due to its angular shape and roughness surface area.

3) As the Aggregate ratio increases the properties of fresh SCC decreases, because segregation and blockage may occur.

4) The andesite raises the compressive strength by (5 to 15$) \%$ compared with the gravel.

5) The ryolite raise the compressive strength by (10 to 25$) \%$ compared with the gravel.

6) The andesite raises the splitting strength by (5 to 12 ) \% compared with the gravel.

7) The ryolite raise the splitting strength by (10 to 20) \% compared with the gravel.

8) The andesite raises the bending strength by (10 to 12) \%compared with the gravel.

9) The ryolite raise the bending strength by and (12 to 17$) \%$ compared with the gravel.

10) $\mathrm{Fsp}=(6-8) \% \mathrm{Fc}, \mathrm{Fb}=(15-18) \% \mathrm{Fc}$

11) The best aggregate ratio for andesite, and ryolite is $5: 2(71.43 \%)$.

\section{Future Recommendation}

1) Creep, shrinkage and modulus of elasticity must be done on the andesite and ryolite mixes.

2) Compressive, splitting, and bending strength tests must be carried out on andesite and ryolite mixes on the long ages, because it has a high content of silica.

3) Using fly ash as mineral additives instead of the silica fume, because it may increase the strength, when using the same proportions.

4) Study the sulphates effect on the all the specimens, especially on ryolite specimens, as it contains a high proportion of silica.

5) Shear test must be done on HSSCC.

6) HSSCC should be exposed to high temperature, especially when it contains silica fume. 
7) The corrosion steel test must be done on the reinforcement concrete which containing andesite and ryolite aggregate.

\section{REFERENCES}

[1] Zongjin., LI, "CIVL 111 Construction Materials", Zhejiang University, 2003, pp.55-60.

[2] Mehta and Monteria, "Concrete Structure, Properties and Materials", Prentice-Hall, INC., Englewood. Cliffs, NJ.

[3] Kosmatka and Panarese, "Design and Control of Concrete Mixtures", lllions, Portland Cement Association, Skokie, 2003.

[4] Gray, S.E., and Bell, J.E., National, "Stone Sand", Engineering Bulletin, Crushed Stone Association, Washington, Vol. 13, 1964, pp. 70.
[5] American Society for Testing and Materials, "Concrete and Nominal Aggregates, Annual Book of ASTM Standards, Part,14,1981.

[6] Stephen. A. Nelson, "General Classification of Igneous Rocks", Tulane University, Jan, 2011.

[7] Hobart King, "Igneous Andesite Rock", www.geology.com,June, 2015.

[8] "Properties of Andesite", www.buzzle.com/articles/properties-anduses-of andesite-rock.html.

[9] Hatem M. El-desoky, "Perlitic Ryolies within Dokhan Volcanic in Eastern Desert Egypt", Al-Azhar Bul.Sci.(8th I.S.C), March, 2012, PP. 29-48.

[10] Egyptian Specification (1109:2008).

[11] The housing and building national research centre.

[12] Egyptian Specification (2421:2009). 